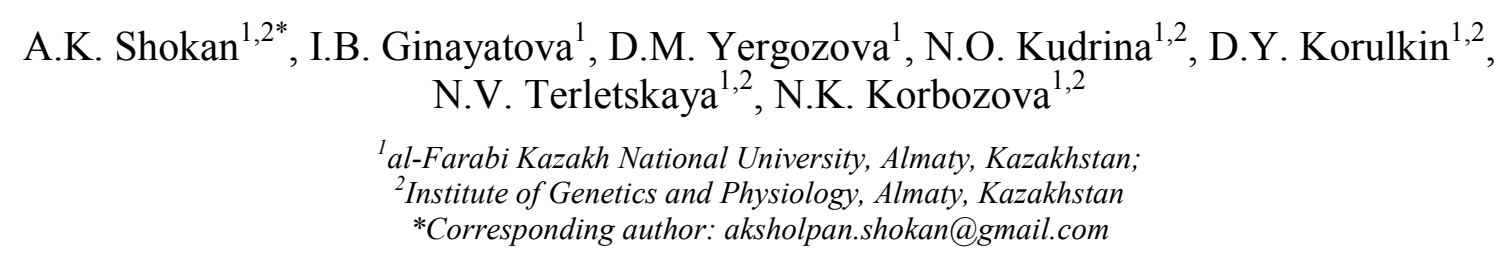

\title{
Effects of Rumex tianschanicus Losinsk extract on hematological indicators in experimental gastritis
}

\begin{abstract}
Gastritis is the most common gastrointestinal disease, with peptic ulcer disease accounting for $30 \%$ of all cases, affecting about $10 \%$ of the global population. According to 2020 statistics, $50,8 \%$ of the population in developing countries suffers from gastritis and this number increasing annually. This study examined the medical effects of Rumex tianschanicus root extract on aspirin induced gastritis in rats. Forty five rats, $250 \pm 50 \mathrm{~g}$ were grouped into two: control group rats received placebo and experimental groups received acetylsalicylic acid $160 \mathrm{mg} / \mathrm{kg}$, orally once daily for 5 consecutive days to induce acute experimental gastritis. Following gastritis registration, rats were grouped into three groups and treated with Rumex tianschanicus L. extract. The first group was given $100 \mathrm{mg} / \mathrm{kg}$ orally once a day for ten days. The second group received 50 $\mathrm{mg} / \mathrm{kg}$ orally once a day for ten days. The third group did not receive the medication. At the end of the study, all the animals were Killed to determine cytological, histological changes and hematological indices. The result showed statistically significant differences $(\mathrm{p} \leq 0,001)$ of total number of leukocytes, total number of erythrocytes, hemoglobin level and content of platelets but they were all within the physiological norm. As a result of the study the Rumex tianschanicus extract pharmacological properties were evaluated and its potential effect on the hematological parameters of rats during the treatment of experimental gastritis accessed. It was discovered that the Rumex tianschanicus extract has no pathological effect on peripheral blood and hemopoiesis during the period of its use. In this regard, the extract of Rumex tianschanicus is recommended for further in-depth research in experimental conditions, followed by a transition to clinical trials.
\end{abstract}

Keywords: gastritis, rats, Rumex tianschanicus, hematology parameters, blood, plant extract.

\section{Introduction}

The problem of gastritis and diseases of gastrointestinal tract has not lost relevance today due to the high prevalence of the disease.

Diseases of the gastrointestinal tract are among the five most common diseases in the world. And out of the total number of gastrointestinal diseases the most common are gastritis and $30 \%$ is due to peptic ulcer disease, this is approximately $10 \%$ of the total population of the globe [1]. Gastritis is thought to affect about half of people worldwide. The incidence rate increases with age [2]. In 2013, about 90 million new cases were reported [3]. And statistics of 2020 shows that globally, $50.8 \%$ of the populations in developing countries suffer from gastritis $[4,5]$. It means that the numbers are increases every year.

The main surface injuries of the mucous membrane are erosions, which have the form of spot hemorrhages [6].

Gastritis, despite the apparent «simplicity» of the disease, continues to create difficulties for clinicians in diagnosis and treatment. Almost half of the global population suffers from diseases of the gastrointestinal tract. Statistics clearly show that in the structure of gastrointestinal diseases, more than $80 \%$ is gastritis [7]. Today, this serious disease affects not only adults, but also school-age children.

Therefore, the treatment of gastritis is relevant, and we propose treatment with sorrel extract, which has low toxicity and is obtained from plant raw materials that grow in our country.

In the Republic of Kazakhstan there is a species of Tien Shan sorrel Rumex tianschanicus, a relative of Rumex. According to G.T. Sitpaeva (2019), Rumex tianschanicus is among the wild varieties of agricultural crops in the Tien Shan of Kazakhstan, which, in addition to other species, are recommended for harvesting as industrial crops. In addition, these studies have revealed that the species Rumex tianschanicus is found in the Kungei Alatau range in the Almaty region, in the Big bare gorge (Bolshoi Zhalanash gorge). They were also found in the Ile-Alatau National Park, also near the Nurly Tau and Tau-Samal microdistricts [8].

Currently, one of the potential ways to improve the efficacy of different disease treatments is to use medicines derived from medicinal plant raw materials. Based on quantitative phytochemical and qualitative 
component analyses, the leaves, stems and roots of Rumex tianschanicus Losinsk contain anthocyanin, anthraquinone, coumarin and flavonoid metabolites [9].

Rumex tianschanicus Losinsk is a medicinal plant that used in folk medicine for diseases of the gastrointestinal tract, liver and many skin pathologies. It contains anthracene derivatives, tannins, flavonoids, naphtols, macro - and microelements, catechins, saponins, alkaloids, polysaccharides, which are responsible for a wide range of therapeutic activity [10].

As Fedulova et al. (2015) noted in their work, it has changes in the hematological blood value of rats taking aspirin are observed.

\section{Material and Methodology}

The material of the study was non-steroidal anti-inflammatory drug aspirin (acetylsalicylic acid, ASA), used to induce gastritis for the subsequent study of the drug based on Rumex tianshanicus. Aspirin causes inflammation on the stomach lining [11].

The object of the study was three-month-old white laboratory rats $(\mathrm{n}=45,22$ females and 23 males). They were placed in different cages to avoid accidental mating. They had a well-balanced diet with vitamins and clean running water before and during the experiments. All experimental studies were carried out in accordance with the rules set out in the manual «Rules for conducting preclinical studies, biomedical and clinical trials in the Republic of Kazakhstan» (dated July 25, 2007 № 442). During the experiment, the behavior and well-being of the animals of the experimental groups was monitored and compared with the behavior and well-being of the control animals.

The experiment consists of two main groups: intact: 15 rats were given placebo, and experiment groups 30 rats were given the aspirin.

The experimental groups of murine were treated with aspirin $160 \mathrm{mg} / \mathrm{kg}$, orally once daily for $5 \mathrm{consec}-$ utive days to induce acute inflammation gastritis [12].

After registration of gastritis rats were grouped into 3 to be treated with medication based on Rumex tianschanicus. First group took $100 \mathrm{mg} / \mathrm{kg}$ for 10 days, orally, once a day. Second group took $50 \mathrm{mg} / \mathrm{kg}$ for 10 days, orally, once a day. Third group did not get the medication.

At the end of the research, animals had been killed under anesthesia [13].

For hematological studies, the blood of rats was collected by cardiac puncture in two separate vial with K3 EDTA and gel with activator. Hematological analyses were performed using Sysmex XS 550-i automatic hematological analyzer (Japan).

The organs of GI tract such as esophagus, stomach, intestine, liver, kidneys and heart was collected for histological preparations in order to determine the effect of the drug in experimental groups of animals. They were weighed and macro photography was taken.

Stomach was dissected out and opened along the greater curvature. The inner surface was rinsed with normal saline to remove food leftovers and blood contaminant, if present. The stomach print was done for cytological examination. Also, it was sent for histological examination in $10 \%$ formalin [14].

The aspirin group's GI tract was carefully studied for the presence of erosions proving the manifestation of acute gastritis. In the rats tested, the erosion of the mucous membrane of stomach and the hyperemia were identified.

A condition in which there is an excess of blood in the vessels of a body organ or tissue is known as hyperemia [15]. As more blood enters the body, the mucous membrane becomes redder (hyperemia) and swells. After that we study the effects of drug based on Rumex tianschanicus at rats which showed signs of stomach inflammation.

From that point, the action of the drug based on Rumex tianschanicus on rats with signs of gastritis was investigated. The gastrointestinal tracts of rats were studied 10 days after the drug was administered.

Macro-images of experimental rats after drug administration revealed that the mucous membrane of the stomach was not exposed to erosion, and thus inflammation was reduced.

The obtained data was statistically processed using standard methods in the program «Statistica-6.0». The Student's t-test was used to determine the significance of the differences in the arithmetic mean. Statistically significant differences were defined as $\mathrm{p}<0,001$. 


\section{Results and Discussion}

According to Muzychkina et al. [9], the root of Rumex tianschanicus contains anthracene derivatives-3methyl-1,8,9,10-tetraoxide dihydroanthracene-9,10 (1,8-dioxy-3-methylanthranol-9,10). The presence of anthracene-derived substances has a positive effect on the gastrointestinal tract of the body [10].

During the experiment, we measured the rats and analyzed their data. Initial weight is $250 \pm 50 \mathrm{~g}$. When taking aspirin, the rat's weight is significantly reduced to $13 \pm 2$ grams. According to our data, due to inflammation of the mucous membranes of the stomach rats could not eat normally. Then after treatment with the drug there is a slight increase in weight up to $8 \pm 3$ grams.

During the period of studies in rats of experimental and control groups, it was noted that the administration of extract did not have visible deviations in the condition of the animals. Before rats took aspirin, they were quite active, mobile, and good at eating food and taking water. During the establishment of gastritis, the activity decreased, the food was eaten poorly, the defecation has changed, and it was liquid. But as soon as they started to ingest the extract, their condition improved. In the following days, the feed intake and water intake significantly increased. They also started to gain weight. The feces were fully formed, acquired a dense consistency. The condition of the animals has stabilized. On the 5th day after applying the extract, their condition improved and there was no gastritis. Our extract also had a good effect on hematopoiesis, erythropoiesis. No side effects of the extract were observed in animals.

Inflammation of the mucous membrane of the stomach, caused by aspirin, is characterized by small erosions $(1-5 \mathrm{~mm})$. As a result, rats eat less or less on an acute basis and weigh less than before. The color of the stomach mucous membrane returned to normal on the fifth day of treatment.

The results of this research of the comparative assessment of the hematological parameters of the observed groups are presented in Table.

$\mathrm{T}$ a b l e

\section{Hematological parameters of blood from rats in the intact group, with gastritis and experimental treatment with Rumex tianschanicus}

\begin{tabular}{|c|c|c|c|c|}
\hline Indicator name, unit of measurement & $\begin{array}{c}\text { International } \\
\text { abbreviation }\end{array}$ & $\begin{array}{l}\text { Control group } \\
\text { (intact) }\end{array}$ & $\begin{array}{l}\text { Acute experi- } \\
\text { mental gastritis }\end{array}$ & $\begin{array}{c}\text { Drug treatment with } \\
\text { Rumex tianschanicus } \\
\text { extract }\end{array}$ \\
\hline The total number of leukocytes, $10^{9} / \mathrm{L}$ & WBC & $6.66 \pm 0.28$ & $8.94 \pm 0.38 *$ & $8.37 \pm 0.36^{*}$ \\
\hline Total red blood cell count, $10^{12} / \mathrm{L}$ & $\mathrm{RBC}$ & $6.31 \pm 0.97$ & $7.06 \pm 1.08$ & $6.50 \pm 1.02$ \\
\hline Hemoglobin level, g/L & HGB & $136.60 \pm 6.23$ & $153.70 \pm 6.01^{*}$ & $153.61 \pm 6.14^{*}$ \\
\hline Total platelet count, $10^{9} / \mathrm{L}$ & PLT & $413.40 \pm 23.00$ & $363.79 \pm 17.80$ & $390.95 \pm 22.70$ \\
\hline Absolute neutrophil count, $10^{9} / \mathrm{L}$ & Neut & $3.03 \pm 0.18$ & $3.92 \pm 0.60 *$ & $3.68 \pm 0.45 * / * *$ \\
\hline Absolute lymphocyte count, $10^{9} / \mathrm{L}$ & Lymph & $3.00 \pm 0.23$ & $4.33 \pm 0.39 *$ & $4.11 \pm 0.27 * / * *$ \\
\hline Absolute content of monocytes, $10^{9} / \mathrm{L}$ & Mono & $0.44 \pm 0.10$ & $0.50 \pm 0.17$ & $0.47 \pm 0.11$ \\
\hline Absolute eosinophil content, $10^{9} / \mathrm{L}$ & Eos & $0.16 \pm 0.05$ & $0.17 \pm 0.10$ & $0.06 \pm 0.02$ \\
\hline The absolute content of basophils, $10^{9} / \mathrm{L}$ & Baso & $0.02 \pm 0.01$ & $0.01 \pm 0.005$ & $0.04 \pm 0.01$ \\
\hline The relative content of neutrophils, $\%$ & Neut & $45.33 \pm 5.53$ & $43.86 \pm 8.67$ & $43.77 \pm 5.09$ \\
\hline The relative content of lymphocytes, $\%$ & Lymph & $45.04 \pm 3.86$ & $48.45 \pm 8.63$ & $49.20 \pm 3.27$ \\
\hline The relative content of monocytes, $\%$ & Mono & $6.84 \pm 1.97$ & $5.56 \pm 1.97$ & $5.76 \pm 1.67$ \\
\hline The relative content of eosinophils, $\%$ & Eos & $2.55 \pm 0.16$ & $1.99 \pm 0.13$ & $0.80 \pm 0.14 * / * *$ \\
\hline The relative content of basophils, $\%$ & Baso & $0.14 \pm 0.03$ & $0.15 \pm 0.01$ & $0.17 \pm 0.09$ \\
\hline
\end{tabular}

As shown in the table, there were statistically significant variations $(p \leq 0,001)$ between the hematological parameters of experimental animals, including the total number of leukocytes, total number of erythrocytes, hemoglobin level and content of platelets, as shown in the Table, but they were all within the physiological norm. When calculating the number of erythrocytes $7.06 \pm 1.08 \times 10^{12} / \mathrm{L}$ in animals of the second group with experimental gastritis, it was discovered that the arithmetic mean values of the amount of these elements are normal and do not differ from significantly the indicators of clinically healthy animals from the 
first $6.31 \pm 0.97 \times 10^{12} / \mathrm{L}$ control group. The statistically significant $(\mathrm{p} \leq 0,001)$ total number of leukocytes with experimental gastritis was $8.94 \pm 0.38 \times 10^{9} / \mathrm{L}$ in comparison with $6.66 \pm 0.8 \times 10^{9} / \mathrm{L}$ in the intact group which indicates the inflammation process. The hemoglobin content in animals with experimental gastritis $13.60 \pm 6.23 \mathrm{~g} / \mathrm{L}$ was significantly different $(\mathrm{p} \leq 0,001)$ in relation to the control group $153.70 \pm 6.01 \mathrm{~g} / \mathrm{L}$. Here we see minor relative changes. Small relative changes were also observed only in the content of platelets in animals of the second group with experimental gastritis $363.79 \pm 17.80 \times 10^{9} / \mathrm{L}$ versus $413.40 \pm 23.00 \times 10^{9} / \mathrm{L}$ of the control group. We assume it is related to aspirin consumption and the thinning effect of aspirin on the blood [16].

The relative content of different types of leukocytes in animals of the second group did not significantly change in relation to the leukogram of control animals.

At the second stage of the study, after applying the correcting gastritis extract of Rumex tianschanicus the following picture was observed: the level of hemoglobin in the third group showed significant $(\mathrm{p} \leq$ $0,001)$ changes $153.61 \pm 6.14$ in relation to control group. In contrast to the control group, the number of leukocytes in the third group increased significantly to $8.37 \pm 0.36 \times 10^{9} / \mathrm{L}$. The number of erythrocytes was without significant changes $6.50 \pm 1.02 \times 10^{9} / \mathrm{L}$. There are no significant changes in number of platelets in the third group $390.95 \pm 22.70 \times 10^{9} / \mathrm{L}$.

Also, we observed the significant difference between absolute neutrophil count $3.68 \pm 0.45 \times 10^{9} / \mathrm{L}$ and absolute lymphocyte count $4.11 \pm 0.27 \times 10^{9} / \mathrm{L}$ of third group in relation to second group and first group. The relative content of different types of leukocytes in the third group of animals did not differ significantly from the leukogram of the other groups of animals, with the exception of a significant $(p \leq 0,001)$ change in the relative content of eosinophils of $0.80 \pm 0.14 \%$ compared to the experimental and intact groups.

Thus, as a result of a comparative analysis of the hematological parameters of three groups: intact, experimental with aspirin only and aspirin with Rumex tianschanicus extract treatment, statistically significant $(\mathrm{p} \leq 0,001)$ changes were revealed, but they were all within the physiological norm.

The food consumption and body weight gain or loss was according to A. Modinat et al (2017). They state that nutrient digestion and absorption by the direct effect on gastric and intestinal mucosal cells have decreased by non-steroidal anti-inflammation drugs (NSAIDs).

According to other [17] researchers investigating the blood parameters in experimental chronic gastritis the content of erythrocytes, hemoglobin in erythrocytes and platelets varied to a low degree in comparison to intact animals indices, in line with the findings of our research. In $27 \%$ of animals an increase leukocytes and monocytes number in the blood, along with increase of all forms of granulocytes in the blood composition: basophilic, neutrophilic, and eosinophilic, indicates the onset of an inflammatory process.

Similar studies [17] have revealed thrombocytopenia associated with a decrease in platelet formation, indicating the presence of acetylsalicylic acid intoxication, which is consistent with our findings. According to other studies [13], aspirin treated groups had lowered RBC and hemoglobin concentration when compared with phytopreparation treated groups.

The established gastroprotective effect of the extract of rumex tianschanicus is due to the synergism of the action of biologically active substances contained in the herbal remedy (flavonoids, tannins, vitamins, organic acids, etc.) [18].

Herbal medicinal products have 5 times less frequent adverse reactions compared for other medications. There is a relatively low toxicity of phytopreparations. It is easy to use them either orally or externally with the procedure used to apply phytopreparations [19].

Phytopreparations are well compatible with synthetic drugs and can greatly improve the therapeutic effects with their appropriate combination. Unlike the synthetic drugs, the phytopreparations have a minimal, medium and normal impact on the body; have a therapeutic effect that develops steadily, but gradually [20].

Similar studies [13] used the Vernonia amygdalina (del.) leaf methanol extract to measure the impact on the stomach ulcer. The therapeutic effect is demonstrated by the presence of alkaloids, flavonoids, tannins, cardiac glycosides and terpenoids.

Phytopreparations are increasingly favored in modern medical practice because of their many beneficial features. They include low-toxicity at optimal effectiveness, a wide variety of treatment effects, a broad organo-protective impact, harmonizing effects on all bodies and processes in the body, minimal side effects and relatively low prices compared to synthetic medicine. 


\section{Conclusion}

There were no deterioration or side effects observed in the rats during the experimental intake of the extract. The rats' condition has stabilized as a result of the treatment.

In this study administration of Rumex tianschanicus extract reduced aspirin-induced gastritis and normalized hematological parameters of rats. Overall, the findings supported the beneficial and non-toxic effects of Rumex tianschanicus extract in preventing gastric ulcer development in experimental acute gastritis rats suggesting the possibility of an alternative gastritis treatment. In addition, the data obtained from experiment indicates there are no toxic and damaging effects of activation and inhibition on hematopoiesis when the extract is administered enterally to rats. Our study found that Rumex tianschanicus root extract with high anthraquinone content has a significant therapeutic effect in the experimental treatment of gastritis.

As a result of the research carried out to evaluatethe pharmacological properties of the Rumex tianschanicus extract and its potential effect on the hematological parameters of rats during the treatment of experimental gastritis, it was discovered that the Rumex tianschanicus extract has no pathological effect on peripheral blood and hemoposes during the period of its use. In this regard, the extract of Rumex tianschanicus is recommended for further in-depth research in experimental conditions, followed by a transition to clinical trials.

\section{References}

1 Snowden F.M. Emerging and reemerging diseases: a historical respective / F.M. Snowden // Immunol. — 2008. — Vol. 225 (1). - P. 9-26.

2 Ferri F.F. Ferri's Clinical Advisor 2013, 5 Books in 1, Expert Consult - Online and Print / F.F. Ferri // Elsevier Health Sciences. - 2012. - P. 165-178.

3 Vos T. Global, regional, and national incidence, prevalence, and years lived with disability for 301 acute and chronic diseases and injuries in 188 countries, 1990-2013: a systematic analysis for the Global Burden of Disease Study 2013 / T. Vos, C. Allen, M. Arora, et al. // The Lancet. - 2015. - Vol. 386, Iss. 10053. - P. 1545-1602.

4 Evelyn P.T. Epidemiological and clinical-pathological aspects of helicobacter pylori infection in brazilian children and adults / P.T. Evelyn, F.M. Fernanda, P.D. Mayra, O.M. Luiz, A.P. Marcela, S.B. Viviane, et al. // Gastroenterology Research \& Practice. 2018. - Vol. 2018. - P. 8-16.

5 Marcis L. Epidemiology of Helicobacter Pylori Infection / L. Marcis, S. Olga, P. Jelizaveta, N. Yaron // Wiley Helicobacter. - 2018. - Vol. 23(1). - e12514.

6 Brooks F.P. The pathophysiology of peptic ulcer disease / F.P. Brooks // Digestive Diseases and Sciences. - 1985. -Vol. 11(30). - P. 15-29.

7 Blaser M.J. Who are we? Indigenous microbes and the ecology of human diseases / M.J. Blaser // EMBO Reports. — 2006. — Vol.7 (10). - P. 956-960.

8 Sitpayeva G.T. Crop wild relatives of Kazakhstani Tien Shan: Flora, vegetation, resources / G.T. Sitpayeva, G.M. Kudabayeva, L.A. Dimeyeva, N.G. Gemejiyeva, P.V. Vesselova // Plant Diversity. — 2020. — Vol. 42, Iss.1. — P. 19-32.

9 Музычкина Р.А. Компонентный состав и биологическая активность полифенольных метаболитов Ruтех tianschanicus Los. / Р.А. Музычкина, Н.В. Курбатова, Д.Ю. Корулькин // Вестн. Казах. нац. ун-та. Сер. биол. — 2016. (69). - P. 22-31.

10 Литвиненко Ю.А. Гепатопротекторная активность фитопрепаратов некоторых казахстанских видов щавелей / Ю.А. Литвиненко, Д.А. Бегимбетова, Т.М. Шалахметова, Р.А. Музычкина// Изв. НАН Республики Казахстан. Сер. хим. 2007.- № 2. - C. 26-28.

11 Vane J.R. The mechanism of action of aspirin / J.R Vane, R.M. Botting // Thrombosis Research. — 2003. — Vol. 110, Iss. 5-6. - P. 255-258.

12 Tantcheva L. Influence of hydrocortisone on the analgesic effect, toxicity and metabolism of aspirin in mice / L. Tantcheva, T. Stoytchev, D. Rangelova // General Pharmacology: The Vascular System. — 1997. — Vol. 28(1). — P. $123-128$.

13 Adefisayo M.A. Gastro-protective effect of methanol extract of Vernonia amygdalina (del.) leaf on aspirin-induced gastric ulcer in Wistar rats / M.A. Adefisayo, R.O. Akomolafe, S.O. Akinsomisoye, Q.K. Alabi, O.L. Ogundipe, J.G. Omole, K.P. Olamilosoye // Toxicology Reports. - 2017. - Vol. 4. - P. 625-633.

14 Blackler R. Gastrointestinal-Sparing Effects of Novel NSAIDs in Rats with Compromised Mucosal Defence / R. Blackler, S. Syer, M. Bolla, E. Ongini, J.L. Wallace // PLOS ONE. — 2012. — Vol. 7(4). — e35196.

15 Larauche M. Effect of dietary nitric oxide on gastric mucosal mast cells in absence or presence of an experimental gastritis in rats / M. Larauche, L. Buéno, J. Fioramonti // Life Sciences. — 2003. - Vol. 73, Iss. 12. — P. 1505-1516.

16 Lee J. Recovery time of platelet function after aspirin withdrawal / J. Lee, J.K. Kim, J.H. Kim, T. Dunuu, S.H. Park, S.J. Park, J.Y. Kang, R.K. Choi, M.S. Hyon // Current therapeutic research, clinical and experimental. — 2014. — Vol. 7. - P. 2631.

17 Федулова Л.В. Взаимосвязь экспериментального гастрита с гематологическими показателями крови / Л.В. Федулова, А.А. Сорокина // Евразийский союз ученых. Биологические науки. — 2015. — № 7 (16). — С. 117-120. 
18 Поветьева Т.Н. Особенности адаптогенного действия лекарственных растений: учеб. / Т.Н. Поветьева, В.Г. Пашинский. — Томск: Изд-во ТПУ, 2005. - 172 с.

19 Николаева И.Г. Разработка и стандартизация средств растительного происхождения, обладающих адаптогенной активностью: автореф. дис. ... д-ра биол. наук / И.Г. Николаева. — Улан-Удэ, 2012. — 48 с.

20 Кривошеева Е.М. Спектр фармакологической активности растительных адаптогенов / Е.М. Кривошеева, Е.В. Фефелова, С.Т. Кохан // Фундаментальные исследования. - 2011. - № 6. - С. 85-88.

\author{
А.Қ. Шоқан, И.Б. Гинаятова, Д.М. Ергозова, Н.О. Кудрина, \\ Д.Ю. Корулькин, Н.В. Терлецкая, Н.К. Корбозова
}

\title{
Rumex tianschanicus Losinsk сығындысының тәжірибелік гастрит кезіндегі гематологиялық көрсеткіштерге әсері
}

\begin{abstract}
Гастрит - бұл асқазан-ішек жолдарының ең көп таралған ауруы, асқазан жарасы ауруы барлық жағдайлардың $30 \%$-ын құрайды, әлем халқының шамамен $10 \%$-ына әсер етеді. 2020 жылғы статистикаға сәйкес дамушы елдер тұрғындарының 50,8 \% -ы гастритпен ауырады және бұл сан жыл сайын артып келеді. Бұл зерттеуде Rumex tianschanicus тамырынан алынған сығындыны егеуқұйрықтарға аспирин беру арқылы туындаған гастритке медициналық әсері зерттелді. Салмағы $250 \pm 50$ г болатын қырық бес егеуқұйрық алынып, екі топқа бөлінді: 1-топтың егеуқұйрықтары (бақылау) плацебо алды, ал 2-топ жедел тәжірибелік гастрит индукциясы үшін күніне бір рет 160 мг/кг ацетилсалицил қышқылын пероральді қабылдады. Гастрит тіркелгеннен кейін егеуқұйрықтар үш топқа бөлініп, Rumex tianschanicus L. сығындысын қабылдады, бірінші топқа күніне бір рет он күн бойы 100 мг/кг пероральді берілді. Ал екінші топ он күн бойы күніне бір рет 50 мг/кг пероральді қабылдады. Үшінші топ Rumex tianschanicus L. сығындысын қабылдаған жоқ. Зерттеу соңында барлық жануарлар цитологиялық, гистологиялық өзгерістер мен гематологиялық көрсеткіштерді анықтау үшін ұйықтатылды. Нәтижеде лейкоциттердің және эритроциттердің жалпы санының, гемоглобин деңгейінің және тромбоциттер құрамының статистикалық маңызды айырмашылықтарын көрсетті ( $\leq$ 0,001), бірақ олардың барлығы физиологиялық норманың шегінде болды. Rumex tianschanicus сығындысының фармакологиялық қасиеттерін және оның тәжірибелік гастритті емдеу кезінде егеуқұйрықтардың гематологиялық параметрлеріне ықтимал әсерін бағалау үшін жүргізілген зерттеу нәтижесі Rumex tianschanicus сығындысы перифериялық қан мен гемопозге (қан түзілу) патологиялық әсер етпейтіні анықталды. Осыған байланысты Rumex tianschanicus сығындысы клиникалық сынақтарды тәжірибелік жағдайда одан әрі тереңірек зерттеу үшін ұсынылған.
\end{abstract}

Кiлm сөздер: гастрит, егеуқұйрықтар, Rumex tianschanicus, гематологиялық көрсеткіштер, қан, өсімдік сығындысы.

\author{
А.К. Шокан, И.Б. Гинаятова, Д.М. Ергозова, Н.О. Кудрина, \\ Д.Ю. Корулькин, Н.В. Терлецкая, Н.К. Корбозова
}

\section{Влияние экстракта Rumex tianschanicus Losinsk на гематологические показатели при экспериментальном гастрите}

\begin{abstract}
Гастрит - наиболее распространенное заболевание желудочно-кишечного тракта, при этом язвенная болезнь составляет $30 \%$ всех случаев, поражая примерно $10 \%$ населения мира. Согласно статистике за 2020 год, 50,8 \% населения развивающихся стран страдает гастритом, и это число ежегодно увеличивается. В статье изучены медицинские эффекты экстракта корня Rumex tianschanicus на индуцированный аспирином гастрит у крыс. Сорок пять крыс весом $250 \pm 50$ г были разделены на две группы: крысы группы 1 (контроль) получали плацебо, а группа 2 получала ацетилсалициловую кислоту 160 мг/кг перорально один раз в день в течение 5 дней подряд для индукции острого экспериментального гастрита. После регистрации гастрита крысы были разделены на три группы и получали экстракт Rumex tianschanicus L. Первой группе давали 100 мг/кг перорально один раз в день в течение десяти дней. Вторая группа получала 50 мг/кг перорально один раз в день в течение десяти дней. Третья группа не получала лекарства. В конце исследования всех животных умерщвляли для определения цитологических, гистологических изменений и гематологических показателей. Результат показал статистически значимые различия ( $\leq 0,001)$ общего количества лейкоцитов, общего количества эритроцитов, уровня гемоглобина и содержания тромбоцитов, но все они были в пределах физиологической нормы. В результате исследования, проведенного для оценки фармакологических свойств экстракта Rumex tianschanicus и его потенциального влияния на гематологические параметры крыс во время лечения экспериментального гастрита, было обнаружено, что экстракт Rumex tianschanicus не оказывает патологического действия на периферическую кровь и кроветворение в период его использования. В
\end{abstract}


связи с этим экстракт Rumex tianschanicus рекомендован для дальнейшего углубленного исследования в экспериментальных условиях с последующим переходом к клиническим испытаниям.

Ключевые слова: гастрит, крысы, Rumex tianschanicus, гематологические показатели, кровь, растительный экстракт.

\section{References}

1 Snowden, F.M. (2008). Emerging and reemerging diseases: a historical respective. Immunol., 225 (1); 9-26.

2 Ferri, F.F. (2012). Ferri's Clinical Advisor 2013,5 Books in 1, Expert Consult - Online and Print. Elsevier Health Sciences.

3 Vos, T., Allen, C. Arora, M. \& al. (2015). Global, regional, and national incidence, prevalence, and years lived with disability for 301 acute and chronic diseases and injuries in 188 countries, 1990-2013: a systematic analysis for the Global Burden of Disease Study 2013. The Lancet, 386 (10053); 1545-1602.

4 Evelyn, P.T., Fernanda, F.M., Mayra, P.D., Luiz, O.M., Marcela, A.P., Viviane, S.B. \& al. (2018). Epidemiological and clinical-pathological aspects of helicobacter pylori infection in brazilian children and adults. Gastroenterology Research \& Practice, $2018 ; 8-16$.

5 Marcis, L., Olga, S., Jelizaveta, P., Yaron, N. (2018). Epidemiology of Helicobacter Pylori Infection. Wiley Helicobacter, 23(1); e12514.

6 Brooks, F.P. (1985). The pathophysiology of peptic ulcer disease. Digestive Diseases and Sciences, 11(30); 15-29.

7 Blaser, M. J. (2006). Who are we? Indigenous microbes and the ecology of human diseases. EMBO Reports, 7 (10); $956-960$.

8 Sitpayeva, G.T., Kudabayeva, G.M., Dimeyeva, L.A., Gemejiyeva, N.G. \& Vesselova, P. V. (2020). Crop wild relatives of Kazakhstani Tien Shan: Flora, vegetation, resources. Plant Diversity, 42, 1; 19-32.

9 Muzychkina, R.A., Kurbatova, N.V. \& Korulkin, D. (2016). Komponentnyi sostav i biologicheskaia aktivnost polifenolnykh metabolitov Rumex transchanicus A. Los. [Component composition and biological activity of polyphenolic metabolites of Rumex tıanschanıcus A. Los.]. Vestnik Kazakhskogo natsionalnogo universiteta. Seriia biologicheskaia - Bulletin of KazNU, series biological, 4(69); 22-31 [in Russian].

10 Litvinenko, Yu.A., Begimbetova, D.A., Shalahmetova, T.M. \& Muzychkina, R.A. (2007). Gepatoprotektornaia aktivnost fitopreparatov nekotorykh kazakhstanskikh vidov shchavelei [Hepatoprotective activity of phytopreparations of some species of Rumex]. Ivestiia Natsionalnoi akademii nauk Respubliki Kazakhstan. Seriia khimicheskaia - New of National Academy of Science, series chemical, 2; 26-28 [in Russian].

11 Vane, J.R \& Botting, R.M. (2003). The mechanism of action of aspirin. Thrombosis Research, 110, 5-6; 255-258.

12 Tantcheva, L., Stoytchev, T. \& Rangelova, D. (1997). Influence of hydrocortisone on the analgesic effect, toxicity and metabolism of aspirin in mice. General Pharmacology: The Vascular System, 28(1); 123-128.

13 Adefisayo, M.A., Akomolafe, R.O., Akinsomisoye, S.O., Alabi, Q.K., Ogundipe, O.L., Omole, J.G. et al. (2017). Gastroprotective effect of methanol extract of Vernonia amygdalina (del.) leaf on aspirin-induced gastric ulcer in Wistar rats. Toxicology Reports, 4; 625-633.

14 Blackler, R., Syer, S., Bolla, M., Ongini, E. \& Wallace, J.L. (2012). Gastrointestinal-Sparing Effects of Novel NSAIDs in Rats with Compromised Mucosal Defence. PLOS ONE, 7(4); e35196.

15 Larauche, M., Buéno, L. \& Fioramonti, J. (2003). Effect of dietary nitric oxide on gastric mucosal mast cells in absence or presence of an experimental gastritis in rats. Life Sciences, 73, 12; 1505-1516.

16 Lee, J., Kim, J.K., Kim, J.H., Dunuu, T., Park, S.H., Park, S.J., et al. (2014). Recovery time of platelet function after aspirin withdrawal. Current therapeutic research, clinical and experimental, 7; 26-31.

17 Fedulova, L.V. \& Sorokina, A.A. (2015). Vzaimosviaz eksperimentalnogo gastrita s gematologicheskimi pokazateliami krovi [Relationship of experimental gastritis to blood hematology]. Evraziiskii soiuz uchenykh. Biologicheskie nauki - Eurasion Unit of scientists, series biology, 7 (16); 117-120 [in Russian].

18 Poveteva, T.N. \& Paşinskii, V.G. (2005). Osobennosti adaptogennogo deistviia lekarstvennykh rastenii [Features of adaptogenic action of medicinal plants]. Tomsk: Izdatelsto Tomskogo pedagogicheskogo universiteta [in Russian].

19 Nikolaeva, I.G. (2012). Razrabotka i standartizasiia sredstv rastitelnogo proishoizhdeniia, obladaiushchikh adaptogennoi aktivnostiu [Development and standardization of plant-based agents with adaptogenic activity]. Thesis PhD. Ulan-Ude [in Russian].

20 Krivosheeva, E.M., Fefelova, E.V. \& Kohan, S.T. (2011). Spektr farmakologicheskoi aktivnosti rastitelnykh adaptogenov [Spectrum of pharmacological activity of plant adaptogens]. Fundamentalnye issledovanie - Fundamental research, 6; 85-88 [in Russian]. 